\title{
Yield and biometry of palisadegrass throughout the seasons of the year
}

\author{
Débora Pantojo de Souza ${ }^{1 *}$, Arthur Carniato Sanches ${ }^{2}$, Fernanda Lamede Ferreira de Jesus ${ }^{1}$, Fernando \\ Campos Mendonça
}

\author{
${ }^{1}$ Agricultural Systems Engineering, Escola superior de Agricultura “Luiz de Queiroz” (ESALQ/USP), CEP: 113418-900, \\ Piracicaba, São Paulo, Brazil \\ ${ }^{2}$ Faculty of Agrarian Sciences, University Federal Grande Dourados, (UFGD) - Dourados, Mato Grosso do Sul, Brazil \\ CEP: 79825-070
}

*Corresponding author: dpdsouza@usp.br

\begin{abstract}
Tropical forage crops present different productive behavior during climatic seasons, because meteorological elements significantly influence the increase or decrease of their forage production and some plant biometric parameters. This work aimed to characterize productive and phytotechnical parameters of palisadegrass under two cultivation systems, single cropped and intercropped (black oats plus ryegrass) during four seasons of one-year period. The experiment was carried out at ESALQ/USP, under a completely randomized statistical design, in two experimental plots with individual area of $144 \mathrm{~m}^{2}$. Irrigation was applied by a sprinkler system with a spacing of $12 \times 12 \mathrm{~m}$. The parameters evaluated were: total forage yield, leaf-stem ratio, final leaf area index ( $\left(\mathrm{LAl}_{\text {final }}\right)$, leaves yield, stems yield, dead material yield, and the mass percentages of leaf, stem and dead material. All over the cycle, the leaf area index (LAI) and canopy height $(\mathrm{CH})$ parameters were measured and correlated with degree-days. The statistical analysis was performed using ASSISTAT 7.7 software. The results showed that the maximum forage yield of single cropped palisadegrass (summer and winter) was 4951.5 and $1318.7 \mathrm{~kg} \mathrm{DM} \mathrm{ha}^{-1}$. The comparison between the sum of yield in all overseeded cropping cycles (4th IS to 8th IS) and the sum of yield in all the single cropping cycles showed a higher yield in the first ones. The $\mathrm{LAI}_{\text {final }}$ also presented similar behavior to the crop yield in the single cropped system all over the year. The estimates for $\mathrm{CH}$ and $\mathrm{LAI}$ from daily air temperature data (degree-days) improve the management of irrigated pastures.
\end{abstract}

Keywords: Pasture irrigation, overseeding, forage yield, leaf area index, plant height.

Abbreviations: TFY_total forage yield, LY_leaf yield, SY_stem yield, DMY_dead material yield, \% LM_percentage of leaf mass, \% SM_percentage of stem mass, \% MDM_percentage of mass of dead material, LS_leaf-stem ratio, LAI final_the final leaf area index, LAI_leaf area index, $\mathrm{CH}_{-}$canopy height, GDD_growing degrees days, IS_intercropping system, SC_single crop.

\section{Introduction}

Tropical forage crops have great seasonal forage yield, with higher production during spring/summer seasons than in autumn/winter seasons. These changes are influenced by climatic elements, such as the soil water availability, daylight availability, solar radiation and lower basal temperature, depending on each forage species (Alencar et al., 2010; Ghosh et al., 2015; Gobbi et al., 2011).

Depending on the local climatic conditions, the use of irrigation will be a determining factor (Ghosh et al., 2015), since the technique ensures an increase in the forage production and livestock rate, compared to non-irrigated pastures. In addition, irrigated pastures reach faster harvest point (by animals or mechanical) due to the higher rate of leaf production (Lopes et al., 2014).

The changes in the phytotechnical patterns with the use of irrigation has been emphasized in several studies (Antoniel et al., 2016; Lopes et al., 2014; Ribeiro et al., 2009; Sanches et al., 2015; Santos et al.; 2013). Production may increase up to $40 \%$ when the crop water demand is supplied by irrigation, together with high soil fertility. Antoniel et al.
(2016) reported yield increases of $36.6 \%$ for irrigated guinea grass Panicum maximum cv. 'Mombasa', and $32.7 \%$ for palisadegrass Urochloa brizantha cv. 'Piatã', from the first to the second cuts, considering the high productive response in relation to evapotranspiration. Also, Dupas et al. (2010) reported a great yield response to irrigation for palisadegrass, $45.7 \%$ higher than the non-irrigated one.

During the dry period, the forage plants close their stomata to avoid excessive water loss to the atmosphere, modifying their entire metabolism, hence, producing less biomass, with alteration of the leaf area (Zanchi et al., 2009).

The leaf area is also influenced by the flow of light intercepted by forage plants. On a several year seasons study, a linear and increasing relationship was observed between the leaf area index (LAI) and intercepted light flow on Urochloa decumbens cv. 'Basilisk', Urochloa brizantha cv. 'Marandu' and Cv. 'Xaraés', Panicum maximum cv. 'Mombasa' and cv. 'Tanzania', and Cynodon spp. cv. Tifton 85 (Borges et al., 2011). These authors suggested that air temperature has a high influence on LAl with different 
responses according to the forage species and cultivar. The lowest value of LAl for Tifton 85 bermuda grass $\left(1.31 \mathrm{~m}^{2} \mathrm{~m}^{-2}\right)$ occurred in July. The other grasses in the experiment showed the lowest LAI value in June.

The influence of air temperature on the plant growth is represented by the accumulation of degree days. That is the daily plant development within its thermal limits, basal temperature (Tb) and upper temperature (TB). Applying this concept to the crop development, it is named as growing degrees day (GDD). Generally, only the basal temperature (Tb) is considered for tropical forage crops, because they develop normally with the highest values of air temperature present in Brazil. So, the Tb values for the genus Urochloa (Syn. Brachiaria) vary from 14.3 to $17.2^{\circ} \mathrm{C}$ (Cruz et al., 2011; Mendonça and Rassini, 2006; Pezzopane et al., 2012).

The meteorological elements (mainly, radiation, rainfall, air temperature) have a high influence on the growth of tropical forage crops and, also, affect the growth of temperate forage species, such as oats and ryegrass. Castro et al. (2012) observed the influence of the temperature on the germination and flowering phases for white oat (Avena strigosa), considering mild temperatures for good germination and warmer for the second phase. In addition, they reported growth limitations influenced by photoperiod and humidity.

The influence of air temperature on the crops is expressed by the accumulation of temperature between upper and lower limiting bands, corresponding to the growth cycle of the species, named as growing degrees days (GDD). Several authors have correlated GDD with biometric parameters, such as leaf area, light interception (Moreno et al., 2014), crop coefficient (Moura et al., 2010; Silva et al., 2012), and also, related to the dry matter yield (Cruz et al., 2011; Pezzopane et al., 2012), generating a better understanding of the crop development in relation to the air temperature surrounding the plant at each moment, which may be adequate, more, or less than the plant needs.

The productive responses of irrigate pastures are different from those non-irrigated. In addition, the insertion of other species with high productive potential reduces the forage gap and raises the nutritional value during the low production season, compensating the investment on the forage seeds.

In addition to the above mentioned methods, the practical method of monitoring the pasture growth with biometric parameters in comparison to degree-days is currently being used by researchers.

It is essential to characterize overseeded systems. Therefore, this study aimed at obtaining a productive and biometric characterization of palisadegrass (Urochloa brizantha cv. Marandu) in two irrigated cropping systems, all over the seasons of the year.

\section{Results and Discussion}

Two different experiments were carried out, one with palisadegrass cultivation conducted in a single cropping system (System 1, area 1, 11 cutting cycles), and another cropping system of the same grass (palisadegrass), intercropped with oats and ryegrass (System 2, area 2, 5 cutting cycles). Both the systems were evaluated separately, and compared in the same period (autumn/winter). In the same period, area 1 had 4 cutting cycles, and area 2, 5 cutting cycles, due to different characteristics of the tropical and the temperate forage crops.

\section{System 1: Yield parameters of Palisadegrass in single cropping}

The total forage yield (TFY) was higher in the summer (cycles 10 and 11), with a maximum TFY of $4951 \mathrm{~kg} \mathrm{ha}^{-1}$, except for the first cycle, which yield was lower $\left(1708 \mathrm{~kg} \mathrm{ha}^{-1}\right)$ and may have been influenced by the standardization cutting (Table 1). Physiologically, the cut after stalk lengthening (60 days after sowing) may have contributed to the elevation of the meristems, and the emission of new basal tillers after the cut may have been necessary. Therefore, there was energy expenditure above what normally occurs, and probably, the established interval ( 28 days) was not enough to allow the plants to reach the maximum productive capacity. Still in TFY, cycles 5 and 6 occurred in the winter period and gave smaller productions (average of $1468 \mathrm{~kg} \mathrm{ha}^{-1}$ ), when the occurrence of days with minimum temperatures between 3 to 5 으, and the mean net radiation of $6.7 \mathrm{MJ} \mathrm{m}^{-2} \mathrm{day}^{-1}$ it were observed (Fig 1).

A productive drop near to $48 \%$ was observed in cycles 2 to 5 . Antoniel et al. (2016) observed average increases of up to $59.4 \%$ in 'Mombasa' guinea grass in the month of November, compared to the cuts observed in July. In the same way, the authors reported a reduction of $40 \%$ in the forage yield of 'Tanzania' guinea grass with the decrease in temperature, radiation and evapotranspiration. Alencar et al. (2013) carried out a study with irrigation and nitrogen (N) fertilization, for palisadegrass and 'Xaraés' grass, guinea grasses 'Mombasa' and 'Tanzania', elephant grass cv. 'Pioneiro', and bermuda grass cv. Estrela. They obtained a mean yield increase of $49.1 \%$ in spring/summer, compared to to autumn/winter, with a variation of the $\mathrm{N}$ doses (100 to $700 \mathrm{~kg} \mathrm{ha}^{-1}$ year $\left.^{-1}\right)$. The authors considered the $\mathrm{N}$ dose of $500 \mathrm{~kg} \mathrm{ha}^{-1}$ year $^{-1}$ as the best result, resulting in a productive forage yield increase of $50.9 \%$, during the spring/summer period. Barbosa et al. (2007) did a similar experiment and obtained a reduction near to $60 \%$ in forage yield during the autumn/winter period, compared to the spring/summer period.

Similar to TFY, the leaf yield (LY) obtained in this work was also higher in summer (cycles 10 and 11) than in winter cycles (5 and 6). This is also a result of the higher forage yield, influenced by the climatic elements, affecting the production and the growth of the stems, which elongates faster at high temperatures. Magalhães et al. (2011) observed smaller pseudo stem elongation rates during the dry period in 'Tanzania' guinea grass. Antoniel et al. (2016) found lower total forage yield in the first crop cycle of 'Piatã' and 'Mombasa' grasses.

In the most productive cycles, the dry matter yield (DMY) was also higher, reflecting the crop growth acceleration, allowing the cuts to be performed before 28 days.

DMY presented a small significant difference between the cycles and was lower (from 0.7 to $8.4 \%$ ) than that found by Barbosa et al. (2007), which obtained about $20 \%$ of DMY for 'Tanzania' guinea grass. Bertolote et al. (2008) found smaller values than the preceding authors, around $11 \%$, for the same grass. The sampling cut performed in palisadegrass at a height of $0.15 \mathrm{~m}$ from the soil avoids the removal of larger amounts of dead material, which is under the soil surface. 
Santos et al. (2013b) obtained up to $5 \%$ of dead material in an experiment with palisadegrass.

\section{Leaf-stem ratio and final leaf area index}

From the leaf-stem ratio (LS), it was observed that during the period with temperature and photoperiod not favorable to forage production of palisadegrass (cycles 5 and 6 , winter), no stem elongation was not observed. The crop remained with reduced height, smaller stem production and with great proportion of leaves in the forage, which led to LS increase. In an experiment of irrigation and cutting cycles of Urochloa decumbens, the LS values were higher than those found by Lopes et al. (2014) for cycles with 28 days, (LS = $0.896)$ in all the cycles. The leaf area index ( LAl $\left._{\text {final }}\right)$ (Table 1$)$ was significantly higher in the months with higher temperature than in the other cycles (mean maximum temperature of $30.5 \circ \mathrm{C})$. Again, it is believed that the standardization cut influenced the LAl final values in cycle 1. Gomide et al. (2009) observed a reduction in LAl with the approach of autumn, and obtained a LAl of 3.1 in the seasonal period, close to that found in this study, with a mean LAl value of 2.9 from cycles 4 to 6 , without significant differences in these cycles. Borges et al. (2011) studied light interception on several forage crops. The authors did not found significant differences in LAl values of palisadegrass in summer. Giacomini et al. (2009) studied the same crop and did not find significant differences between the $L A I_{\text {final }}$ values over the four climatic seasons, but the differences were observed between canopy heights and time of cutting (percentage of light interception). It is possible to separate the cycles in four phases, except for the first cycle, with less production due to the influence of the standardization cut for the establishment and growth of tillers. In the following phases observed as below: the first phase is observed in grouping cycles 2 to 4 during autumn; the second phase on cycles 5 and 6 , at winter; and the third phase with the cycles 7 to 9 occurred in spring; and fourth phase, cycles 10 and 11 in summer. The two last phases were the most productive, with the maximum development of tropical forages.

\section{System 2: Comparison of palisadegrass single cropped and overseeded cropped}

\section{Yield parameters}

System 2 (Intercropping system) consisted of palisadegrass, black oats and ryegrass, whose cuts were carried out at variable time intervals, according to the development of the temperate forage crops. Table 2 shows Tukey test results for the following variables: TFY, LY, SY, DMY, LS and LAI.

The comparison of single cropping and intercropped system showed significant differences for all the evaluated parameters. The highest TFY demonstrated in Table 2 was observed in the intercropped cycles 6 and 7, and in the single cropped cycle 7. However, when the sum of the single cropping cycles (7505.33 $\mathrm{kg} \mathrm{ha}^{-1}$ ) is compared to the intercropping system (11343.74 $\left.\mathrm{kg} \mathrm{ha}^{-1}\right)$, the productive difference reached $34 \%$ higher for the intercropped cycles. The $L Y$ in the intercropped cycles was also higher than the in the single cropped palisadegrass. In cycle 4 , both plots were represented mainly by palisadegrass, and black oat and ryegrass represented approximately $15 \%$ of the dry yield. In the other intercropped cycles, up to $97 \%$ of LY was composed by black oat and ryegrass crops. The botanical separation between black oats and ryegrass was not carried out. However, it is well known that ryegrass production occurs later compared to black oats (Carvalho et al., 2011; Olivo et al., 2010), which indicates the predominance of black oat in cycle 5 and an increasing participation of ryegrass from cycle 6 onwards. Duchin et al. (2013) studied the cultivation of black oat with ryegrass in Santa Catarina, and observed that ryegrass provided one more cut cycle, compared to oats, with higher yields in the last two cycles, because it showed a rapid stem elongation. In this experiment, the predominance of ryegrass in the intercropping cycles 7 and 8 was observed, maintaining the yield similar to the other autumn/winter cycles. This is confirmed by the predominance of stems in cycle 7, with an yield of $1495.38 \mathrm{~kg} \mathrm{ha}^{-1}$, with a slight decrease in the LAI (4.96). The ryegrass leaves are thin and succulent and after drying they result in a relatively smaller leaf mass. Moreover, by the rapid stem elongation and the preflowering of the plants, there was a decrease in the number of leaves. With the increase in minimum temperature from September $6^{\text {th }}, 2016$ (beginning of cycle 8), there was an inhibition of ryegrass plants growth and a longer time for inflorescence stem formation, and the leaves represented the highest percentage of mass. Similarly, Neal et al. (2009) observed a reduction in the production of ryegrass with the increase of temperature. Sanches et al. (2015) evaluated the overseeding of oats in a pasture of bermuda grass cv. Tifton 85 , and observed that the forage yield was composed by $57 \%$ of leaves and $29 \%$ of stems. In the intercropped cycles $\left(5^{\text {th }}\right.$ for $\left.8^{\text {th }}\right)$ of this experiment (Table 2$)$, the mean forage yield was composed by $60 \%$ of leaves and $38 \%$ of stems. Excluding the cycle 4th IS with predominance of palisadegrass represented higher percentage of leaf, compared to other cycles, because its leaves are larger. The leaf-stem ratio (LS) showed significant differences between the cuts, with higher values in all the single cropping cycles and in the $4^{\text {th }}$ intercropped cycle, when $75.9 \%$ of the forage production corresponded to the leaves of palisadegrass. In the following cycles, the LS were lower, close to 2 . Sanches et al. (2015) obtained a mean value of LS 2.5 in Tifton grass overseeded with black oats.

The lowest values of the final leaf area index (LAI) were found for the two single cropped cycles 5 and 6, during the winter, clearly characterizing the seasonal production.

\section{Correlations between biometric parameters and degrees- day}

Figures 3 and 4 show correlations between LAl and forage canopy height $(\mathrm{CH})$, with the estimated LAl every 4 days all over the cropping cycles, and with the growing degrees day (GDD), with data grouped by climatic seasons.

In both the parameters ( $\mathrm{LAl}$ and $\mathrm{CH}$ ) the adjustments for spring, summer and autumn correlations showed coefficients of determination higher than 0.84 , being adjusted in a potential model for all stations, for the LAI $x$ GDD correlation. Other authors proposed some empirical models with GDD observed with $\mathrm{R}^{2}$ adjustments varying between 0.73 and 0.87 (Cruz et al., 2011; Pezzopane et al., 2012). 
Table 1. TFY_total forage yield, $L Y$ _ leaf yield, $S S_{-}$stem yield, $D M Y$ _dead material yield, $L S_{-}$leaf-stem ratio, $L A l_{\text {final }}$ the final leaf area index, comparison single Marandu grass over year. Results with the same letters do not differ significantly by the Tukey's test $\mathrm{p} \leq 0.01$ ). Variation coefficients: $20.21 \%$ (TFY), $16.88 \%$ (LY), 33.38\% (SY), 105.59\% (DMY), $49.16 \%$ (LS), $16.81 \%\left(\mathrm{LAl}_{\text {final }}\right)$.

\begin{tabular}{|c|c|c|c|c|c|c|c|c|c|c|c|c|c|}
\hline \multirow{2}{*}{$\frac{\text { Cycle }^{1}}{1}$} & \multirow{2}{*}{$\begin{array}{l}\text { Date (month/day) } \\
02 / 11-03 / 09\end{array}$} & \multirow{2}{*}{$\begin{array}{l}\text { TFY } \\
1708.3\end{array}$} & \multicolumn{2}{|r|}{ LY } & \multirow{2}{*}{\multicolumn{2}{|c|}{$\begin{array}{l}\text { SY } \\
413.7\end{array}$}} & \multicolumn{2}{|c|}{ DMY } & \multicolumn{3}{|c|}{$\mathrm{LS}$} & \multicolumn{2}{|c|}{$\mathrm{LAl}_{\text {final }}$} \\
\hline & & & $\mathrm{C}$ & 1294.6 & & & $b$ & 138.4 & $a b$ & 3.3 & $\mathrm{~b}$ & 2.5 & $\mathrm{C}$ \\
\hline 2 & 03/10 - 04/06 & 2542.9 & $\mathrm{bc}$ & 1942.7 & def & 600.2 & $\mathrm{~b}$ & 22.5 & $\mathrm{~b}$ & 5.3 & $\mathrm{~b}$ & 3.9 & bc \\
\hline 3 & 04/07 - 05/04 & 2307.1 & $\mathrm{bc}$ & 1885.0 & def & 422.2 & $b$ & 67.2 & $b$ & 4.6 & $\mathrm{~b}$ & 3.8 & bc \\
\hline 4 & $05 / 05-06 / 13$ & 1998.8 & bc & 1659.2 & def & 339.7 & $b$ & 40.4 & $\mathrm{~b}$ & 5.2 & $\mathrm{~b}$ & 3.4 & bc \\
\hline 5 & $06 / 14-07 / 23$ & 1318.7 & $\mathrm{c}$ & 1168.2 & $f$ & 150.5 & $b$ & 120.4 & $a b$ & 8.0 & $a b$ & 2.3 & $\mathrm{c}$ \\
\hline 6 & $07 / 24-09 / 01$ & 1617.3 & $\mathrm{C}$ & 1411.5 & ef & 205.8 & $b$ & 14.9 & $b$ & 7.3 & $\mathrm{~b}$ & 3.0 & bc \\
\hline 7 & 09/02 - 10/11 & 2570.5 & $\mathrm{bc}$ & 2377.1 & bcd & 193.4 & $b$ & 35.3 & $b$ & 15.1 & $\mathrm{a}$ & 4.3 & $\mathrm{~b}$ \\
\hline 8 & $10 / 12-11 / 08$ & 2580.8 & bc & 2235.5 & cde & 345.4 & $b$ & 20.2 & $b$ & 6.6 & $\mathrm{~b}$ & 4.5 & $\mathrm{~b}$ \\
\hline 9 & $11 / 09-12 / 06$ & 3222.8 & $\mathrm{bc}$ & 2903.3 & $a b c$ & 319.5 & $\mathrm{~b}$ & 58.7 & $\mathrm{~b}$ & 9.3 & $a b$ & 6.5 & $a$ \\
\hline 10 & $12 / 07-01 / 03$ & 4951.5 & $\mathrm{a}$ & 3555.4 & $a$ & 1396.1 & $\mathrm{a}$ & 89.4 & $\mathrm{~b}$ & 2.7 & $\mathrm{~b}$ & 7.9 & a \\
\hline 11 & $01 / 04-01 / 31$ & 4725.2 & $\mathrm{a}$ & 3145.5 & $a b$ & 1579.7 & $\mathrm{a}$ & 308.2 & a & 2.0 & $\mathrm{~b}$ & 6.5 & $\mathrm{a}$ \\
\hline
\end{tabular}

* Lowercase letters differ the lines (cycles). ${ }^{1}$ Productive Cycles: 1 to 3 and 8 to 11 duration of 28 days per cycle; 4 to 7 duration of 40 days per cycle.

Table 2. TFY_total forage yield, $L Y \_$leaf yield, $S Y$ _ stem yield, $D M Y \_$dead material yield, LS_leaf-stem ratio, $L A l_{\text {final _final leaf area }}$ index, comparison during the autumn winter Marandu grass in IS_ intercropping system, and SC_single crop. Results with the same letters do not differ significantly by the Tukey's test $p \leq 0.01$ ). Coefficients of variation of the intercropping cycles: $23.43 \%$ (TFY), $23.09 \%$ (LY), 26.43\% (SY), 79.91\% (DMY), $50.95 \%$ (LS), 25.32\% (LAl $\left.\mathrm{Linal}_{\text {al }}\right)$.

\begin{tabular}{|c|c|c|c|c|c|c|c|c|c|c|c|c|c|}
\hline Cycle $^{1}$ & Date $^{2}$ & TFY & & LY & & SY & & DMY & & LS & & $L A l_{\text {fina }}$ & \\
\hline $4^{\text {th }}$ IS & $05 / 05-06 / 13$ & 1827.37 & $a b$ & 1642.24 & $a b c$ & 185.13 & e & 13.87 & b & 8.87 & $a b$ & 6.74 & $a$ \\
\hline $4^{\text {th }} \mathrm{SC}$ & $05 / 05-06 / 13$ & 1998.83 & $a b$ & 1659.17 & $a b c$ & 339.67 & de & 40.37 & $a b$ & 5.22 & bcd & 3.37 & bc \\
\hline $5^{\text {th }}$ IS & $06 / 14-07 / 11$ & 1735.87 & $a b$ & 1200.35 & bc & 535.52 & $\mathrm{~cd}$ & 34.60 & $\mathrm{~b}$ & 2.25 & bcd & 7.02 & a \\
\hline $5^{\text {th }} \mathrm{SC}$ & $06 / 14-07 / 23$ & 1318.70 & $b$ & 1168.20 & $b c$ & 150.50 & e & 120.40 & a & 7.97 & bc & 2.33 & c \\
\hline $6^{\text {th }}$ IS & $07 / 12-08 / 04$ & 2748.90 & a & 1923.90 & $a b$ & 825.00 & bc & 47.10 & $a b$ & 2.34 & bcd & 6.89 & a \\
\hline $6^{\text {th }} \mathrm{SC}$ & $07 / 24-09 / 01$ & 1617.30 & $a b$ & 1411.50 & bc & 205.80 & de & 14.90 & $b$ & 7.34 & bcd & 2.96 & c \\
\hline $7^{\text {th }}$ IS & $08 / 05-09 / 05$ & 2554.80 & a & 1059.42 & $c$ & 1495.38 & a & 15.40 & $b$ & 0.71 & d & 4.96 & $a b c$ \\
\hline $7^{\text {th }} \mathrm{SC}$ & $09 / 02-10 / 11$ & 2570.50 & a & 2377.10 & $\mathrm{a}$ & 193.40 & e & 35.30 & $b$ & 15.06 & $a$ & 4.29 & $a b c$ \\
\hline $8^{\text {th }}$ IS & 09/06 - 10/07 & 2476.80 & $a b$ & 1582.37 & $a b c$ & 894.43 & $b$ & 59.80 & $a b$ & 1.72 & $\mathrm{~cd}$ & 6.25 & $a b$ \\
\hline
\end{tabular}

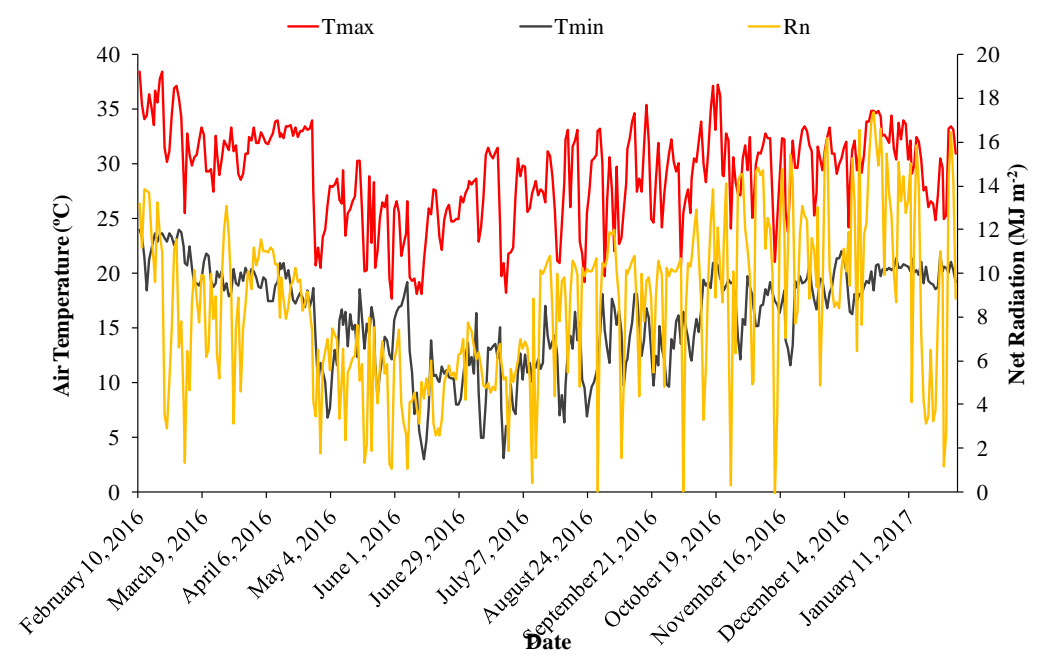

Fig 1. Climatic data measured by the ESALQ meteorological station in the period between February $10^{\text {th }} 2016$ and January $31^{\text {th }}$, 2017, Net radiation (Rn), Maximum and minimum temperatures (Tmin and Tmax) during the development of crop cycles. Piracicaba / SP, 2017. 


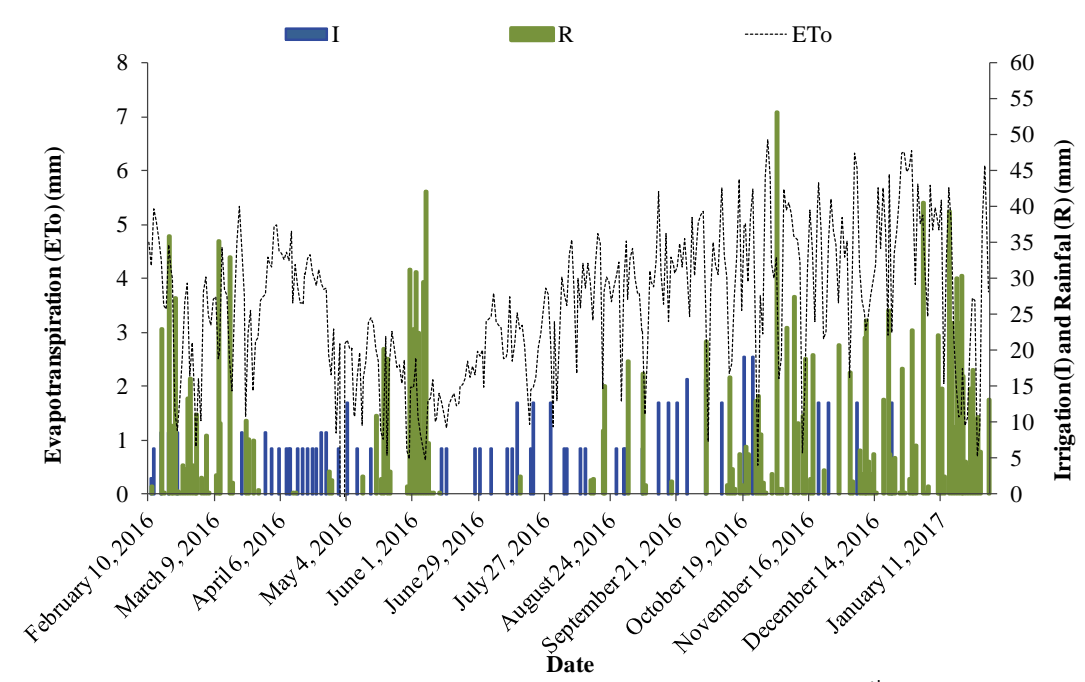

Fig 2. Climatic data measured by the ESALQ meteorological station, between February $10^{\text {th }} 2016$ and January $31^{\text {th }} 2017$, Reference evapotranspiration (ETo) and rainfall (R), Irrigation (I) applied in the experimental plots during the same period. Piracicaba / SP, 2017.

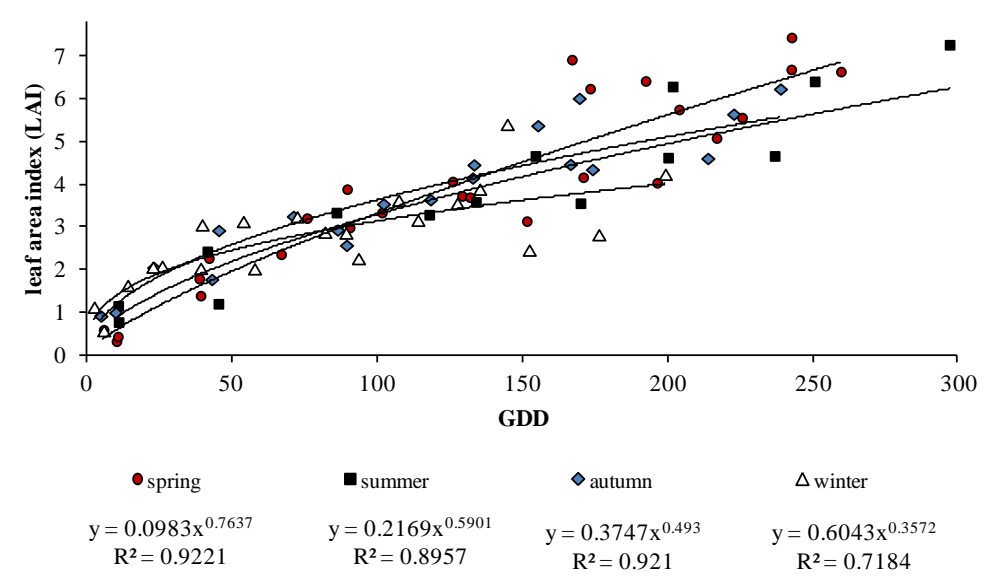

Fig 3. Correlation between leaf area index (LAI) and growing degrees days (GDD) for palisadegrass throughout the seasons. Graphical representations and regression adjustment spring $(\bullet)$, summer $(\boldsymbol{\square})$, autumn $(\diamond)$ and winter $(\Delta)$.

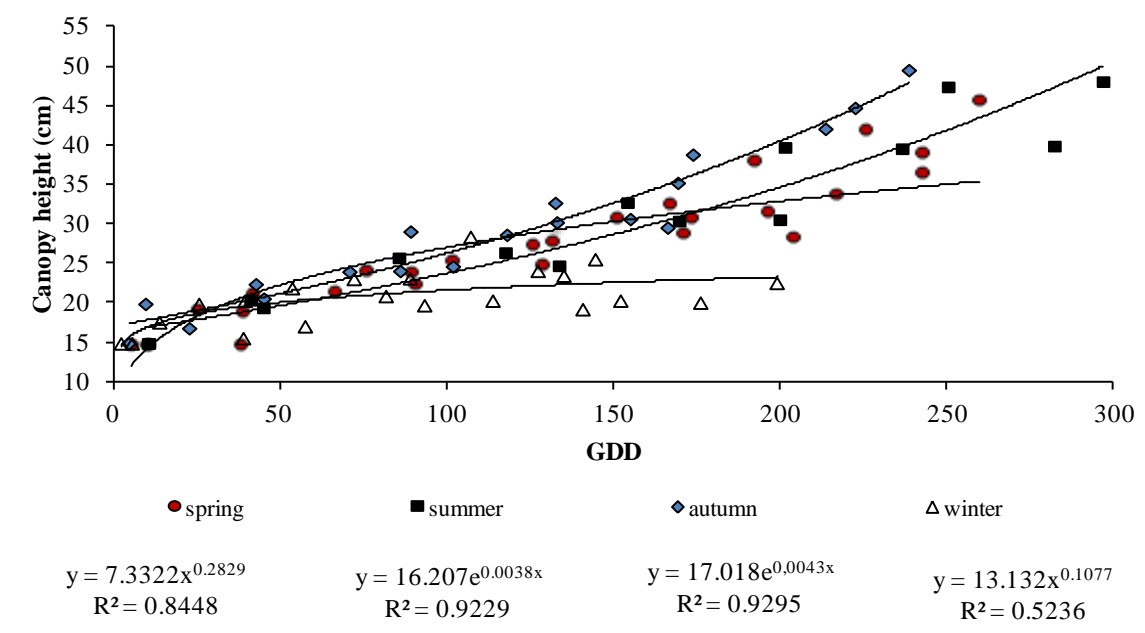

Fig 4. Correlation between forage canopy height $(\mathrm{CH})$ and growing degrees days (GDD) for palisadegrass throughout the seasons. Graphical representations and regression adjustment spring $(\bullet)$, summer $(\boldsymbol{\square})$, autumn $(\diamond)$ and winter $(\Delta)$. 


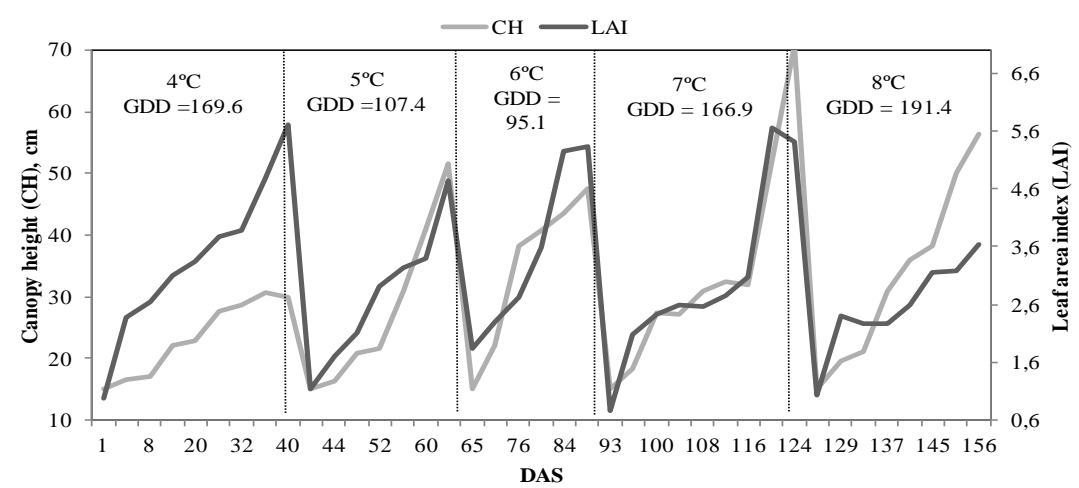

Fig 5. Leaf area index (LAI) and forage canopy height $(\mathrm{CH})$ over the palisadegrass cycles intercropped with oat and ryegrass during the autumn/winter in days after the start (DAS) and growing degree days (GDD) per cycle.

The data obtained in the winter showed a lower correlation adjustment than other seasons. The seasonal production significantly influenced the forage yield and the growing behavior of palisadegrass. As previously reported, the nonstem elongation added to the low leaf expansion during the winter resulted in low forage yield and a in a different result for the determination coefficient adjustment for the correlation of $\mathrm{CH}$ with GDD (Fig 4).

No correlation was proposed for overseeded cropping cycles, since the basal temperature for temperate forage crops, black oats and ryegrass, are different and smaller in relation to the palisadegrass, making it difficult to correctly interpret the behavior of these crops growing together. In this case, Figure 5 demonstrates the $\mathrm{CH}$ and LAl data for the overseeded cropping cycles, pointing to accumulation in GDD for each cycle. The highest canopy height was observed in cycle 7 due to the higher presence of stems in the samples.

\section{Materials and methods}

\section{Location, soil classification}

The experiment was carried out at the "Luiz de Queiroz" School of Agriculture (ESALQ / USP) in two experimental plots with a total area of $288 \mathrm{~m}^{2}$. The soil of the area is classified as eutroferric red nitosol (Santos et al., 2013), with a layer of up to $0.4 \mathrm{~m}$ : $32.5 \%$ of sand, $18.95 \%$ of Silt and 48.6 of clay.

The soil chemical characteristics were determined before the assembly of the experiment in the Laboratory of Soil Fertility of ESALQ/USP. The $0-0.4 \mathrm{~m}$ layer had the following characteristics: $\mathrm{pH}=5.1 ; \mathrm{P}_{(\text {resin) }}=52 \mathrm{mg} \mathrm{dm}^{-3} ; \mathrm{K}=0.69 \mathrm{cmol}_{\mathrm{c}}$ $\mathrm{dm}^{-3} ; \mathrm{Ca}=2.6 \mathrm{cmol}_{\mathrm{c}} \mathrm{dm}^{-3} ; \mathrm{Mg}=1.4 \mathrm{cmol}_{\mathrm{c}} \mathrm{dm}^{-3} ; \mathrm{H}+\mathrm{Al}=3.65$ $\mathrm{cmol}_{\mathrm{c}} \mathrm{dm}^{-3} ; \mathrm{Al}=0.2 \mathrm{cmol}_{\mathrm{c}} \mathrm{dm}^{-3} ; \mathrm{V}=54 \%$.

Conventional soil preparation (plowing and harvesting), weed control, correction of $\mathrm{pH}$ with liming and establishment fertilization were carried out, as recommended by Raij et al. (1996).

\section{Plant materials}

The tropical forage species was palisadegrass (Urochloa brizantha cv. Marandu), that manually seeded in two experimental similar plots, in both of which there was only the palisadegrass, then one remained in single crop and the other received the black oats (Avena strigosa) and ryegrass (Lolium multiflorum).

\section{Experimental design}

The experimental area had two plots of total area of $144 \mathrm{~m}^{2}$. Because of this the statistical analysis was based on the comparison over time, considering the cycles of cultivation as treatments in a completely randomized design with four replications.

Two different experiments were carried out: single cropped palisadegrass (System 1 with 11 cutting cycles), and intercropped palisadegrass overseeded with black oat and ryegrass (System 2 - with 9 cutting cycles), evaluated separately, and compared in the same autumn/winter period.

\section{Climatic characteristics, irrigation systems and management}

The meteorological data used were collected at the ESALQ Meteorological Station, located near the experimental area. Figures 1 and 2 show the variations of the maximum (Tmax) and minimum (Tmin), net radiation ( $R n)$, rainfall, irrigation and reference evapotranspiration (ETo) values.

The plots were irrigated by conventional sprinkler system, using sprinklers with sectorial mechanism and flow of $590 \mathrm{~L}$ $\mathrm{h}^{-1}$, which application uniformity was tested and the Christiansen Uniformity Coefficient (CUC) was $87 \%$. The application rate of the sprinklers (Ai) was $12.3 \mathrm{~mm} \mathrm{~h}^{-1}$, running at a pressure of $245 \mathrm{kPa}$.

The water depth (WD) to be applied was determined by the volume consumed by lysimeter ratio (liters) and the same area (square meters) with effective depth (Z) equal to 580 $\mathrm{mm}$. The irrigation interval previously established was based on a limit of $70 \%$ of the water availability factor $\left(\theta_{70}=\right.$ humidity at $70 \%)$. Moisture at the field capacity $\left(\Theta_{\mathrm{fc}}\right)$ and current humidity $\left(\theta_{c}\right)$ were estimated by means of the soil water retention curve, obtained with the aid of a tension table and a Richards extractor, at the Soil and Water Quality Laboratory of ESALQ / USP and adjusted by the Van Genuchten model (Genuchten, 1980). The irrigation events are shown in Figure 2. 


\section{Conduction of experiment}

After germination and establishment of palisadegrass, the experiment was started with a standardization cut at a height of $0.15 \mathrm{~m}$ from the soil, using a costal brush cutter. The two experimental plots were similarly conducted at the beginning, in both there was only the palisadegrass, then one remained in single crop and the other retained the black oats (Avena strigosa) and ryegrass (Lolium multiflorum).

The first three crop cycles had an interval of 28 days between cuts and the crop water consumption evaluations were performed for each cut, according to the methodology used by Pequeno et al. (2015). With the change of climatic elements, the interval between cuts was changed to 40 days in the plot with the single cropped palisadegrass. In the second plot ('Marandu' overseeded with black oat and ryegrass), the harvest was performed after the pasture reached $95 \%$ luminous interception (LI), in which situation the pseudo stem elongation is expected to be reduced, since this type of management reduces the accumulation of pseudo stems and the deposition of senescent material (Magalhães et al., 2011).

The first cut of the intercropping period of area 2 ('Marandu' + black oat + ryegrass) followed the recommendation for tropical forage species and occurred when the plants started the stem elongation stage, occurring 35 days after emergence. The regrowth cuts followed with varying intervals between 24 and 32 days (Primavesi et al., 2001).

The plots were fertilized with urea after each cut, at $80 \mathrm{~kg}$ ha ${ }^{-1}$ during spring, summer, and $50 \mathrm{~kg} \mathrm{ha}^{-1}$ during autumn and winter.

The determination of the biomass accumulation was quantified with four subsamples per plot. They were cut manually at $0.25 \mathrm{~m}^{2}(0.5 \times 0.5 \mathrm{~m})$ area. The cutting was performed on forage inside the plot up to the predefined height as residue $(0.15 \mathrm{~m})$. The forage samples collected were subdivided into leaves, hems + stems and dead material, and then weighed and placed in a forced ventilation oven at $65^{\circ} \mathrm{C}$ for 72 hours, and weighed again.

After this procedure, the following productive components were estimated (all in $\mathrm{kg} \mathrm{ha}^{-1}$ ): TFY_total forage yield, LY_ leaf yield, SY_ stem yield, DMY_dead material yield; and the percentage of dry matter (\% DM), also the leaf-stem ratio (LS).

The final leaf area index $\left(\mathrm{LAl}_{\text {final }}\right)$ was estimated at the end of each cycle by the destructive method, by randomly collecting the leaves of 10 tillers per plot, weighing and passing the material through a leaf area integrator model LI$3100 \mathrm{C}$ (Li-Cor). After this procedure, the samples were placed in a forced ventilation oven at $65^{\circ} \mathrm{C}$ for 72 hours and weighed again. With these data, the specific leaf area and the final LAl were calculated.

\section{Calculation of accumulated growing degree-days (GDD)}

The GDD was calculated according to the simple triangulation methodology proposed by Snyder, (1985), according to the occurrence condition: 1- Lower basal temperature of the crop ( $\mathrm{Tb}$ ) lower than the minimum temperature of the day (Equation 1); 2- Lower basal temperature greater than the minimum temperature of the day (Equation 2).

$$
\begin{aligned}
& =\frac{(\mathrm{TM}+\mathrm{Tm})}{2} \\
& -\mathrm{Tb}
\end{aligned}
$$

$\frac{\left[(\mathrm{M}-\mathrm{Tb})\left(\frac{\pi}{2}-\theta\right)+(\mathrm{W} \cos \theta)\right]}{\pi}$

Em que,

$D_{\mathrm{n}}$ - degree-days

$M$ - Average daily temperature in ${ }^{\circ} \mathrm{C}$;

$\mathrm{TM}$ - Maximum daily temperature in ${ }^{\circ} \mathrm{C}$;

$\mathrm{Tm}$ - Minimum daily temperature in ${ }^{\circ} \mathrm{C}$;

$\mathrm{Tb}$ - Basal temperature for culture, considered 15ㅇ;

$\mathrm{W}-\mathrm{W}=\frac{\mathrm{TM}-\mathrm{Tm}}{2}$

$\theta-\theta=\operatorname{arcsen}\left(\frac{\mathrm{bt}-\mathrm{M}}{\mathrm{W}}\right)$

The daily values of DG were added by each cultivation cycle. The result was the GDD in the different seasons, being correlated with leaf area index (LAI) and forage canopy height $(\mathrm{CH})$. Both measurements were performed every 4 days throughout the cycle. The LAI was estimated with a LAI $2000\left(\right.$ Li-Cor $\left.^{\circledR}\right)$ apparatus and collected at 10 points per plot, each point consisted of 1 measurement at the top (zero point - full radiation) and two measurements at ground level. The readings were always made in the early morning or late afternoon, to avoid errors arising from the interference of incident solar radiation. The $\mathrm{CH}$ was measured with a graduated scale of 6 points per plot.

\section{Statistical analysis}

For statistical analysis, the ASSISTAT 7.7 software (Silva and Azevedo, 2002) was used to perform the analysis of variance and the means comparison test.

\section{Conclusion}

For the palisadegrass, the first crop cycle after the standardization cut resulted in a less forage yield. The following cycles presented distinct performances, superior forage yield in spring/summer and lower in autumn/winter. In single cropping, most of the forage yield was composed by leaves, during the seasonal period. The plants reached lower heights with lower stem production, so the leaf-stem ratio was higher during the winter. However, the number of leaves was also low compared to the other cycles, resulting in a lower leaf area index in the winter. During the autumn/winter period, the palisadegrass overseeded with black oat and ryegrass presented a higher forage yield than the single cropped palisadegrass. There was a predominance of ryegrass in cycles 7 and 8 and after that, a growth inhibition of temperate forage crops with the increase in temperature. The leaf-steam ratio was lower in the intercropping cycles than in the single cropping ones, with higher final leaf area index in intercropping system compared to single cropping. In both the parameters, crop height $(\mathrm{CH})$ and leaf area index (LAI), adjustments of $\mathrm{CH}$ and LAl correlations with GDD for spring, summer and autumn seasons have demonstrated good adjustments for potential or exponential empirical models. 


\section{Acknowledgments}

The authors thank to the Sao Paulo Research Foundation (FAPESP) for the financial support of this work with the regular research project $\mathrm{n}$-2012/23002-6.

\section{References}

Alencar CAB de, Cóser AC, Martins CE, De Oliveira RA, Cunha FF da, Figueiredo JLA (2010) Altura de capins e cobertura do solo sob adubação nitrogenada, irrigação e pastejo nas estações do ano. Acta Sci - Agron. 32(1): 21-27.

Alencar CAB de, Cunha FF da, Martins CE, Cóser AC, Oliveira RA de, Araújo RAS (2013) Adubação nitrogenada e estações anuais na produção de capins irrigados no leste mineiro sob corte. Rev Bras Saúde e Produção Anim. 14(3): 413-425.

Antoniel LS, Prado G do, Tinos C, Beltrame GA, Almeida JVC de, Cuco GP (2016) Pasture production under different irrigation depths. Rev Bras Eng Agríc Ambient. 20(6): 539544.

Barbosa RA, Nascimento D do, Euclides VPB, Silva SC da, Zimmer AH, Torres R ADA (2007) Capim-tanzânia submetido a combinações entre intensidade e frequência de pastejo. Pesqui Agropec Bras. 42(3): 329-340.

Bertolote LEM, Campana M, Oliveira PPA, Gomes JP, de Morais RG (2008) Produção de forragem e qualidade de genótipos de aveia sobressemeadas em capim-tanzânia. Paper presented at Reunião Anual da Sociedade Brasileira de Zootecnia, 2008.

Borges BMMN, Silva Júnior LC da, Lucas FT, Silva WJ da (2011) Relação entre o fluxo luminoso interceptado em diferentes épocas no índice de área foliar de diferentes forrageiras. Semin Ciências Agrárias. 32(4): 1589-1594.

Carvalho PC de F, Santos DT dos, Gonçalves EN, Moraes A de, Nabinger C (2011) Forrageiras de clima temperado In: D. M. da Fonseca and J. A. Martuscello (Eds.), Plantas Forrageiras $1^{\text {st }}$ edn. UFV Viçosa, MG.

Castro GS, Costa CHM da, Ferrari Neto J (2012) Ecofisiologia da aveia branca. Sci Agrar Parana. 11(3): 1-15.

Cruz PG da, Santos PM, Pezzopane JRM, Oliveira PPA, de Araujo LC (2011) Modelos empíricos para estimar o acúmulo de matéria seca de capim-marandu com variáveis agrometeorológicas. Pesq Agropecu Bras. 46(7): 675-681.

Duchini PG, Guzatti GC, Ribeiro Filho HMN, Sbrissia AF (2014) Tiller size/density compensation in temperate climate grasses grown in monoculture or in intercropping systems under intermittent grazing. Grass Forage Sci. 69(4): 655-665.

Dupas E, Buzetti S, Sarto AL, Hernandez FBT, Bergamaschine AF (2010) Dry matter yield and nutritional value of Marandu grass under nitrogen fertilization and irrigation in cerrado in São Paulo. Rev Bras Zootec. 39(12): 2598-2603.

Ghosh PK, Palsaniya DR, Rai AK, Kumar S (2015) Strategies for higher nutrient use efficiency and productivity in forage crops. In: Rakshit A, Singh HB, Sen A (ed), Nutrient use efficiency: from basics to advances, New Delhi, Springer India.

Giacomini AA, Silva SC da, Sarmento DO de L, Zeferino CV, Souza JSJ, Trindade JKda, Guarda Vdel'A, Nascimento Júnior D do (2009) Growth of marandu palisadegrass subjected to strategies of intermittent stocking. Sci Agric. 66(6): 733-741.
Gobbi KF, Garcia R, Ventrella MC, Fróes A, Neto G, Rocha GC (2011) Área foliar específica e anatomia foliar quantitativa do capim-braquiária e do amendoim-forrageiro submetidos a sombreamento. Rev Bras Zootec. 40(7): 1436-1444.

Gomide CAde M, Reis RA, Simili FF, Moreira AL (2009) Atributos estruturais e produtivos de capim-marandu em resposta à suplementação alimentar de bovinos e a ciclos de pastejo. Pesq Agropec Bras. 44(5): 526-533.

Lopes MN, Pompeu RCIFF, Silva RG da, Filho José G L R, Lacerda CF de, Bezerra MA (2014) Fluxo de biomassa e estrutura do dossel em capim-braquiária manejado, sob lâminas de irrigação e idades de crescimento. Biosci J. 30(2): 490-500.

Magalhães M de A, Martuscello JA, Fonseca DM da, Oliveira IM de, Freitas FP de, Faria DJG, Oliveira RA de, Júnior José IR (2011) Influência da irrigação, da densidade de plantio e da adubação nitrogenada nas características morfogênicas, estruturais e de produção do capimtanzânia. Rev Bras Zootec. 40(11): 2308-2317.

Mendonça FC and Rassini JB (2006) Temperatura-base inferior e estacionalidade de produção de gramíneas forrageiras tropicais. Circ. Técnica 45.

Moreno LSB, Pedreira CGS, Boote KJ, Alves RR (2014) Base temperature determination of tropical Panicum spp. grasses and its effects on degree-day-based models. Agric For Meteorol. 186: 26-33.

Moura CRW, Zolnier S, Ribeiro A, Oliveira RAde (2010) Coeficiente de cultura da alface hidropônica baseado no conceito de graus-dia. Ceres 57(2): 224-233.

Neal JSA, Fulkerson WJB, Lawrie RC, Barchia IMA (2009) Difference in yield and persistence among perennial forages used by the dairy industry under optimum and deficit irrigation. Crop Pasture Sci. 60 1071-1087.

Olivo CJ, Meinerz GR, Agnolin CA, Steinwandter E, Ziech MF, Skonieski FR (2010) Produção de forragem e carga animal de pastagens de Coastcross sobressemeadas com forrageiras de inverno. Rev Bras Zootec. 39(1): 68-73.

Pequeno DNL, Pedreira CGS, Sollenberger LE, de Faria AFG, Silva LS (2015) Forage accumulation and nutritive value of brachiaria grasses and Tifton 85 bermudagrass as affected by harvest frequency and irrigation. Agron J. 107(5): 17411749.

Pezzopane JRM, Santos PM, Mendonça FC, de Araujo LC, da Cruz PG (2012). Dry matter production of Tanzania grass as a function of agrometeorological variables. Pesq Agropec Bras. 47(4): 471-477.

Primavesi AC, Primavesi O, Chinelato AC, Godoy R (2001) Indicadores de determinação de cortes de cultivares de aveia forrageira. Sci Agric. 58(1): 79-89.

Raij B van, Catarella H, Quaggio JA, and Furlani AMC (1996) Recomendações de adubação e calagem para o estado de São Paulo, 2nd edn. Instituto Agronômico de Campinas, Fundação IAC, Campinas, São Paulo.

Ribeiro EG, Fontes CA de A, Palieraqui JGB, Cóser AC, Martins CE, da Silva RC (2009) Influência da irrigação, nas épocas seca e chuvosa, na produção e composição química dos capins Napier e Mombaça em sistema de lotação intermitente. Rev Bras Zootec. 38(8): 1432-1442.

Sanches AC, Gomes EP, Rickli ME, Fasolin JP, Soares MR C, Goes RHTB de (2015) Produtividade e valor nutritivo do capim Tifton 85 irrigado e sobressemeado com aveia. Rev Bras Eng Agríc Ambient. 19(2): 126-133. 
Santos PM, Cruz PG da, Araujo LC de, Pezzopane JRM, Valle CB do, Pezzopane C de Gi (2013) Response mechanisms of Brachiaria brizantha cultivars to water deficit stress. Rev Bras Zootec. 42(11): 767-773.

Santos HG dos, Jacomine PKT, Anjos LHC dos, Oliveira VÁ de, Lumbreras JF, Coelho MR, Almeida JA de, Cunha TJF, Oliveira JB de (2013) Sistema brasileiro de classificação de solos, 3rd edn. Rio de Janeiro, Embrapa Solos Brasília, Distrito Federal.

Silva ALBO, Pires RCM, Ribeiro RV, Machado EC, Rolim GS (2012) Consumo de água de variedades de cana-de-açúcar irrigadas por gotejamento subsuperficial. Paper presented at Inovagri International Meeting, May Fortaleza. 2012
Silva F de A and Azevedo CAV de (2002) Versão do programa computacional Assistat para o sistema operacional Windows. Rev Bras Prod Agroindustriais. 4(1):71-78.

Snyder RL (1985) Hand calculating degree days. Agric For Meteorol. 35(1-4): 353-358.

van Genuchten MTH (1980) A closed-form equation for predicting the hydraulic conductivity of unsaturated soils 1. Soil Sci Soc Am J. 44(5):892-987.

Zanchi FB, Waterloo MJ, Aguiar LG, von Randow C, Kruijt B, Cardoso FL, Manzi AO (2009) Estimativa do índice de área foliar (IAF) e biomassa em pastagem no estado de Rondônia, Brasil. Acta Amaz. 39(2): 335-348. 